\title{
Origin of magmatism of the Sredinny Range, Kamchatka, constrained by noble gas isotopes
}

\author{
MASAO FUKAGAWA ${ }^{1}$, ANNA VOLYNETS ${ }^{2,3}$, \\ HIROCHIKA SUMINO ${ }^{1}$, TATIANA CHURIKOVA ${ }^{2,3}$, \\ MARIA PEVZNER ${ }^{4}$ AND YURI TARAN ${ }^{3}$ \\ ${ }^{1}$ The University of Tokyo \\ ${ }^{2}$ Universitaet Goettingen \\ ${ }^{3}$ Institute of volcanology and seismology FEB RAS \\ ${ }^{4}$ Geological Institute RAS \\ Presenting Author: hmo0926zzz@yahoo.co.jp
}

Pliocene-Quaternary volcanism in Kamchatka occurs in three volcanic chains parallel to the trench: Eastern volcanic front, Central Kamchatka Depression and the Sredinny Range (SR). Origin of Quaternary volcanism in the SR is controversial. Compositional variability of the SR volcanic rocks is explained by participation of several components in melting -depleted mantle wedge, subduction fluid and HFSE-enriched component, which invokes various geodynamic models including postsubduction setting, back-arc condition of the contemporary arc system, mantle plume, melting of the slab edge, trench rollback, etc. Noble gas isotopes can be good tracers of the origin of magmatism because they have different features in different geochemical reservoirs such as convecting MORB-source mantle, deep-mantle and crust. To constrain the origin of the SR magmatism, we analyzed noble gases ( $\mathrm{He}, \mathrm{Ne}, \mathrm{Ar}, \mathrm{Kr}$, and $\mathrm{Xe}$ ) in olivines and pyroxenes separated from basalts and basaltic andesites collected from the SR.

Helium isotope ratios $\left({ }^{3} \mathrm{He} /{ }^{4} \mathrm{He}\right.$ ratios $)$ of the samples are divided into three groups. Most of the samples (group 1) are in the range of MORB-source mantle $(8 \pm 1 \mathrm{Ra})$, where Ra denotes atmospheric ${ }^{3} \mathrm{He} /{ }^{4} \mathrm{He}$ ratio. These rocks were produced by the Late Quaternary monogenetic edifices. Group 2 includes low- ${ }^{3} \mathrm{He} /{ }^{4} \mathrm{He}$ rocks of Pliocene-Quaternary age, and group 3 low ${ }^{3} \mathrm{He} /{ }^{4} \mathrm{He}$ Miocene-Pliocene plateau lavas. With one exception, all low- ${ }^{3} \mathrm{He} /{ }^{4} \mathrm{He}$ rocks are found within the eastern slopes of the SR main watershed. The MORB-like ${ }^{3} \mathrm{He} /{ }^{4} \mathrm{He}$ ratios for the Quaternary extinct volcanic complexes of the SR are in contrast with the lower (on average) values measured in olivines from active volcanoes of the Eastern Kamchatka. The variations in ${ }^{3} \mathrm{He} /{ }^{4} \mathrm{He}$ values in the rocks of different volcanic complexes of the SR do not correlate with other isotopic systems $(\mathrm{Sr}, \mathrm{Nd}$, and $\mathrm{Pb}$ ), which show rather uniform ranges. Location of the low- ${ }^{3} \mathrm{He} /{ }^{4} \mathrm{He}$ rocks on the eastern slopes of the SR main watershed is consistent with the excess amount of fluid involved in the mantle metasomatism in comparison with the more remote parts of the SR, which might have been replenished by the MORB-like He due to the asthenosphere upwelling in the backarc conditions. 